Article

\title{
Evaluating the Effectiveness of Rhizobium Inoculants and Micronutrients as Technologies for Nepalese Common Bean Smallholder Farmers in the Real-World Context of Highly Variable Hillside Environments and Indigenous Farming Practices
}

\author{
Malinda S. Thilakarathna ${ }^{1}$, Tejendra Chapagain ${ }^{1}$, Bhawana Ghimire ${ }^{2}$, Roshan Pudasaini ${ }^{2}$, \\ Bir Bhahadur Tamang ${ }^{2}$, Khem Gurung ${ }^{2}$, Khem Choi ${ }^{2}$, Laxmi Rai ${ }^{2}$, Samjhana Magar ${ }^{2}$, \\ Bishnu BK ${ }^{2}$, Shankar Gaire ${ }^{3}$ and Manish N. Raizada ${ }^{1, *}$ \\ 1 Department of Plant Agriculture, University of Guelph, 50 Stone Road, Guelph, ON N1G 2W1, Canada; \\ mthilaka@uoguelph.ca (M.S.T.); tejendra@uoguelph.ca (T.C.) \\ 2 Local Initiatives for Biodiversity, Research and Development (LI-BIRD), Box 324, Pokhara 33700, Nepal; \\ Bhawana.Ghimire@uga.edu (B.G.); rpudasaini@libird.org (R.P.); btamang@libird.org (B.B.T.); \\ khemg212@gmail.com (K.G.); krchowi@gmail.com (K.C.); laxmirai2029@gmail.com (L.R.); \\ samjhana.sinjalipak@gmail.com (S.M.); bisu490bishwakarma@gmail.com (B.B.) \\ 3 Department of Plant Pathology, Agriculture and Forestry University, Rampur, Chitwan 44209, Nepal; \\ spgaire@gmail.com \\ * Correspondence: raizada@uoguelph.ca; Tel.: +1-(519)-824-4120 (ext. 53396)
}

Received: 7 December 2018; Accepted: 8 January 2019; Published: 12 January 2019

\begin{abstract}
Studies have shown the potential of rhizobia and associated micronutrients to enhance symbiotic nitrogen fixation in legumes. Tens of millions of smallholder farmers, however, farm on mountain hillsides in highly variable soil and microenvironments, with different crop rotations, inputs and cultural practices. Here, on the terraces of the Nepalese Himalayas, we evaluated rhizobium inoculants (local, exotic), micronutrients (molybdenum, boron) and their combinations as technologies for smallholder farmers under highly variable microenvironments and traditional practices. The study was conducted as a series of participatory on-farm trials with 39 terrace farmers in two mid-hill districts of Nepal (Dhading, Kaski) from 2015 to 2017. Plots were measured for relevant agronomic traits. As expected, when comparing treatment plots with adjacent control plots within each farm, the results demonstrated tremendous farm-to-farm variability for nodulation, vegetative biomass, shoot nitrogen content, grain yield, and grain $\mathrm{N}$ content. Despite the variation observed, the data showed that the number of farms that showed yield increases from the rhizobium interventions, compared to those that suffered yield losses, was generally 2:1. We discuss potential experimental and socio-agronomic reasons for the variable results, including rainfall, which appeared critical. The results demonstrate the promise of rhizobium interventions for hillside smallholder farmers, even in a highly variable context.
\end{abstract}

Keywords: common bean; legume; nodule; nitrogen fixation; terrace farmer; micronutrients

\section{Introduction}

Legumes are important sources of high quality, plant-based protein, especially in developing countries, associated with nitrogen $(\mathrm{N})$ rich biomass and seeds [1-4]. The nitrogen is derived from their association with symbiotic rhizobia that fix atmospheric nitrogen gas into ammonia [5,6]. Legumes deposit this fixed $\mathrm{N}$ into soil as root exudates [7,8] as well as through litter decomposition [9], 
thus reducing the need for synthetic $\mathrm{N}$ fertilizers for associated non-legumes. Legumes are therefore critical to intercropping/mixed cropping systems [9-11], and crop rotations with cereal crops [6,12]. However, some legume species and varieties suffer from sub-optimal symbiotic nitrogen fixation (SNF) due to unavailability of compatible rhizobium strains in the soil, unfavorable soil conditions (e.g., salinity) for the rhizobia/symbiosis, and soil nutrient deficiencies, including for the micronutrients, molybdenum (Mo), a co-factor for the rhizobium nitrogenase enzyme, and boron (B), which helps to stabilize nodular cell walls and peribacteroid/infection thread membranes [13-16].

Globally, common bean (Phaseolus vulgaris L.) is the dominant grain legume of subsistence smallholder farming households, who consume its protein rich pods/beans as green vegetables, immature seeds, and mature seeds. Common bean originated in the Americas, but it is now the major source of dietary protein for smallholders in South Asia, Latin America, and Eastern Africa [17]. Common beans are highly diverse in terms of morphology, cultivation methods, uses, and cultural practices [18]. Under subsistence farming conditions, common bean can be grown as a sole crop, intercropped (row or mixed) with cereals (e.g., maize), and/or relay intercropped with cereals (e.g., maize) [19]. Unfortunately, the common bean is inadequately adapted to extreme environmental conditions (e.g., drought, heat, salinity/alkalinity) [20]. Furthermore, common bean suffers from low yields, and the quality of its seed protein remains suboptimal [18].

Compared to other grain legumes, common bean derives a comparatively small fraction of its nitrogen input from symbiotic nitrogen fixation [21], but vast genotypic variability exists among different bean varieties for SNF [22]. On average, $36 \%$ of common bean $\mathrm{N}$ can be derived from SNF (\%Ndfa) under farmers' field conditions [5]. Many studies have shown that rhizobium inoculants can improve nodulation, nitrogen fixation, and grain yield of common bean in real-world subsistence farmers' fields [23-27]. It is also important to note that sometimes a rhizobium inoculant alone does not benefit plant growth and yield in farmers' fields $[28,29]$. Beneficial effects of rhizobia on grain yield can be enhanced by introducing additional interventions along with rhizobium inoculants (e.g., application of phosphorus $(\mathrm{P})$, organic manure, lime) $[23,24,30]$ including micronutrients (specifically Mo and B) which have been shown to increase nodulation, SNF, and grain yield in common bean [30-35]. The important question is to what extent these simple interventions can benefit smallholder subsistence farmers under heterogenous soil, climatic, and cultural practices.

Millions of rural people around the world depend on farming on hillsides that experience variable soil and microenvironmental conditions, and are subject to different crop rotations, crop varieties, inputs, and indigenous farming practices [36,37]. The major challenges encountered by hillside farmers are a lack of quality land area for agriculture (small household farm size), and low yields associated with low soil fertility, erosion, poor access to extension services and agricultural inputs (e.g., farmyard manure, inorganic fertilizer), lack of mechanization, labor shortages, poverty, and illiteracy [36]. Amongst hillside smallholder farms there is extensive farm-to-farm variability for grain yield in common bean, which is associated with the above noted variations, along with variation in hillside topology, soil fertility, access to organic and inorganic fertilizers, household resources, gender, and access to staking materials [38].

In Nepal, the majority of agricultural lands consist of smallholder farms located on hillsides and mountains, where common bean is the dominant legume crop in traditional crop rotations [39]. Nepalese smallholder farmers generally grow common bean on low fertility soils. Nepalese soils are typically deficient in some critical micronutrients required for SNF (specially B and Mo) due to the underlying bedrock, which has a low nutrient content, combined with high erosion on hillsides, intensive cropping, and low input replenishment associated with poverty [40]. In our experience, Nepalese hillside farmers, in part due to their remoteness and lack of resources, mostly use untreated seeds from the previous season to cultivate this crop, and do not apply rhizobium inoculants, micronutrients, or other inputs. Systemic on-farm trials are lacking to test the real-world effectiveness of rhizobium inoculants and associated micronutrients on common bean smallholder farms located on the country's highly heterogeneous hillsides, which, like other mountainous regions, are characterized 
by a diversity of ethnic groups, indigenous farming practices, soils, microenvironments, and crop rotations [37].

The objective of this research was to determine the effectiveness of rhizobium inoculants (native and exotic rhizobia) and associated SNF-boosting micronutrients (B and Mo) on nodulation, plant growth, grain yield, and tissue $\mathrm{N}$ content in common bean grown by smallholder hillside farmers in Nepal under highly variable environments and traditional farming practices, and in the absence of other co-interventions. The study was conducted as a series of participatory on-farm trials with 39 terrace farmers in two mid-hill districts of Nepal (Dhading, Kaski) for two rotation cycles from 2015 to 2017.

\section{Materials and Methods}

\subsection{Study Site, Climate, and Soil}

This study was conducted in two mid-hill districts of Nepal, namely Dhading and Kaski (Figure 1a), for two rotation cycles from 2015 to 2017. Research was conducted on terraced farmers' fields under natural climatic conditions. The sites were previously used for grain production (maize-millet-rice) and managed using farm yard manures (FYM), very limited chemical fertilizers (i.e., urea), and no plant protection compounds. The experimental sites in Dhading were located at $27^{\circ} 78^{\prime} 84^{\prime \prime} \mathrm{N}$ and $84^{\circ} 70^{\prime} 02^{\prime \prime} \mathrm{E}$, at an altitude of 700-1300 $\mathrm{m}$ above sea level (masl), while the sites in Kaski were situated at $28^{\circ} 20^{\prime} 25^{\prime \prime} \mathrm{N}$ and $84^{\circ} 11^{\prime} 71^{\prime \prime} \mathrm{E}$, at an altitude of 1100 masl.

Climatic data for the experiment were collected from a regional weather station at each research site (Figure 2a-d). The temperature profiles during the growing seasons were similar in both production years and sites, peaking during the growing season during August-September and then declining (Figure 2a-d). The average daytime temperature over the cropping seasons (August-December, 2015/16) was $20.4{ }^{\circ} \mathrm{C}$ in Kaski and $22{ }^{\circ} \mathrm{C}$ in Dhading, with the warmest days at both sites in August. With respect to rainfall, in 2015, Kaski received $1525 \mathrm{~mm}$ total rainfall during the common bean crop season (August-December) (Figure 2a), whereas Dhading only received $328 \mathrm{~mm}$ during this period (Figure 2c). A similar trend was found in 2016, where $1610 \mathrm{~mm}$ of rainfall was received in Kaski from August-December (Figure 2b), in comparison to $1107 \mathrm{~mm}$ in Dhading (Figure 2d).

Soil samples were collected $(0-20 \mathrm{~cm})$ from each farmer's field at each test site $(n=10$ per site) at the time of plot establishment in 2015 only; from each farm, 5-6 samples were collected and pooled. The soils were analyzed at the Local Initiatives for Biodiversity, Research and Development (LI-BIRD) laboratory (Pokhara, Nepal) for $\mathrm{pH}$ (using a soil water solution of 1:2.5 $w t / v)$, organic matter (Walkley-black method), total N (Modified Kjeldahl method), available P (Bray-P1 method), and available $\mathrm{K}$ (flame photometer with $1 \mathrm{M}$ ammonium acetate extracting solution) [41] (Supplementary Table S1). In general, the soils at both Kaski and Dhading were moderately well drained, coarse textured sandy loam with low to moderate fertility. The soil was acidic in farms located at Kaski ( $\mathrm{pH}$ 5.14-5.44), whereas other soil chemical properties were highly variable including: soil organic matter content (30.9-53.3 $\mathrm{g} \mathrm{kg}^{-1}$ dry soil), total $\mathrm{N}\left(1.6-3.6 \mathrm{~g} \mathrm{~N} \mathrm{~kg}^{-1}\right.$ dry soil), available $\mathrm{P}_{2} \mathrm{O}_{5}$ (3.2-249.0 $\mathrm{g} \mathrm{kg}^{-1}$ dry soil), and available $\mathrm{K}_{2} \mathrm{O}$ (53.6-89.0 $\mathrm{g} \mathrm{kg}^{-1}$ dry soil). Similarly, farms located at Dhading also had heterogeneous soil properties for soil $\mathrm{pH}$ (6.02-6.98), organic matter content (26.2-47.0 $\mathrm{g} \mathrm{kg}^{-1}$ dry soil), total $\mathrm{N}\left(1.5-4.2 \mathrm{~g} \mathrm{~N} \mathrm{~kg}^{-1}\right.$ dry soil), available $\mathrm{P}_{2} \mathrm{O}_{5}$ (17.2-156.5 $\mathrm{g} \mathrm{kg}^{-1}$ dry soil), and available $\mathrm{K}_{2} \mathrm{O}\left(66.6-227.9 \mathrm{~g} \mathrm{~kg}^{-1}\right.$ dry soil) (Supplementary Table S1). Unfortunately, soils were not sampled in 2016. 



Figure 1. Participatory on-farm trials in the mid-hills region of Nepal (Kaski and Dhading districts). (a) Map of Nepal showing the geographical location of the trial sites (green color). (b) Seeding of common bean plots in terrace farm fields by Local Initiatives for Biodiversity, Research and Development (LI-BIRD) staff. (c) Application of micronutrients (Mo and B) after one week of germination by LI-BIRD staff. (d) Traditional manual weeding practices carried out by farmers under the supervision of LI-BIRD staff. (e-g) Different trellis practices used by individual farmers in Kaski during 2015. (h) Common bean plots at the pod filling stage. 


\subsection{Experimental Design}

Trials were conducted in 10 farmers' fields $(n=10)$ at each site (except $n=9$ at Kaski-2016). The experimental design consisted of five treatments (T1-T5) in 2015 and six treatments (T1-T6) in 2016: T1, not inoculated with rhizobia and no micronutrients (i.e., control); $\mathrm{T} 2$, micronutrient treatment (boron (B) + molybdenum (Mo)); T3, inoculated with a reference (exotic) rhizobium strain (USDA 9030); T4, inoculated with the respective reference rhizobium strain $+\mathrm{B}+\mathrm{Mo}$; $\mathrm{T}$, inoculated with locally isolated indigenous rhizobia; T6, inoculated with the respective local rhizobia $+\mathrm{B}+$ Mo. Details of the micronutrient concentrations and rhizobium origins/treatments are noted below. Each farm received all treatments, arranged in a randomized complete block design (RCBD) relative to other farms. An individual farm was one replicate. Each farm household prepared their own plots using their traditional practices (e.g., livestock-driven plough), but under the guidance of LI-BIRD field staff. LI-BIRD staff performed the rhizobium inoculations, seed sowing, and micronutrient applications (Figure 1b,c). The plots were then maintained by each household using traditional practices, including weeding, and managed equally across treatments (Figure 1d). LI-BIRD staff collected samples for data analysis.

\subsection{Plant Materials, Rhizobium Strains, and Inoculum Preparation}

A local Nepalese variety of common bean (Phaseolus vulgaris cv. Four Season Bean) was used at both sites for both production years, for which seeds were obtained from Anamolbiu seed company in Nepal. For T5 and T6, the local indigenous rhizobium was collected by Shankar Gaire (Agriculture and Forestry University, Chitwan), who isolated it from root nodules of a locally grown common bean variety (Four Season Bean) in Chitwan, Rampur, located in the tropical, flat Terai region of Nepal, according to the standard protocol [42]. For T3 and T4, the exotic reference rhizobium strain for common bean was Rhizobia tropici USDA 9030 [43]. The rhizobium strains (USDA 9030 and local rhizobia) were grown in yeast mannitol (YM) as liquid cultures for 5 days at $28{ }^{\circ} \mathrm{C}$. Finely ground low grade peat soil $(<2 \mathrm{~mm})$ was used as the rhizobium carrier material, where $1 \mathrm{~kg}$ of peat soil was mixed with sucrose $(10 \mathrm{~g})$, peptone $(1 \mathrm{~g})$, calcium carbonate $(1 \mathrm{~g})$, sodium propionate $(10 \mathrm{~g})$, and water $(50 \mathrm{~mL})$ to support optimum growth and establishment of the rhizobia on the carrier. To prepare the inoculants, the final rhizobium cell density was adjusted to $\mathrm{OD}_{595}=1.0$ and uniformly mixed with the peat soil, which was pre-autoclaved, at a rate of $12.5 \mathrm{~mL} / 100 \mathrm{~g}$ peat soil and incubated for three days before seed application. Seeds were inoculated with the rhizobia at a rate of $10 \mathrm{~g}$ inoculant per $100 \mathrm{~g}$ of seeds. Gum arabic solution $(40 \% \mathrm{w} / \mathrm{v})$ was used $(2 \mathrm{~mL} / 100 \mathrm{~g}$ seeds) as an adhesive agent to assure that the rhizobium inoculants coated the seeds well. Seed inoculation with rhizobia was carried out by LI-BIRD staff at each farm before planting, as demonstrated by the N2Africa project (https:/ / www.youtube.com/watch?v=4rexSZR-QH0), and the treated seeds were stored under shade until seeding.

\subsection{Planting and Application of Micronutrients ( $B$ and Mo)}

Plots were prepared on terraces (Figure 1b). Each plot measured $5 \mathrm{~m} \times 6 \mathrm{~m}$, wherein common bean seeds were planted at $80 \mathrm{~cm}$ (row spacing) $\times 40 \mathrm{~cm}$ (within row) (Figure 1e). Seeding was carried out from late August to early September in the Kaski and Dhading districts in 2015 and 2016. For T2, T4, and T6, micronutrients ( $\mathrm{B}$ and Mo) were side dressed one week after germination by LI-BIRD staff at a rate of $300 \mathrm{~g} B$ per ha ( $2 \mathrm{~kg}$ borax per ha) and $150 \mathrm{~g}$ Mo per ha (326 g sodium molybdate per ha) (Plant-Prod ${ }^{\circledR}$ Brampton, ON, Canada). They were applied to both sides of the plants, $10 \mathrm{~cm}$ away from the stem and at a $5 \mathrm{~cm}$ depth (Figure 1c). Bamboo or wood sticks were used as trellises (Figure 1e-g).

\subsection{Sample Collection}

Plant samples were taken by LI-BIRD staff at flowering stage and maturity. At flowering, three plants were randomly collected from the middle of each subplot for nodule number, nodule dry weight (DWT), and shoot (leaves and stem) and root DWT. Dry weight of tissue samples was 
determined after drying samples for $72 \mathrm{~h}$ in an oven at $65{ }^{\circ} \mathrm{C}$. Dried shoot samples were ground and analyzed for total $\mathrm{N}(\%)$ according to the modified Kjeldahl method [41]. Total $\mathrm{N}$ content of shoot tissue was calculated by multiplying shoot DWT by shoot $\mathrm{N}(\%)$. At maturity, seeds were collected from a $3 \mathrm{~m} \times 3 \mathrm{~m}$ area from each subplot. Seed samples were dried, and the moisture content was determined. The final seed weight was expressed at $13 \%$ moisture content. Seed samples from 2016 were analyzed for total N (\%) according to the modified Kjeldahl method. Seed N content was calculated by multiplying seed DWT at $13 \%$ moisture content by seed $\mathrm{N}(\%)$.

\subsection{Statistical Analysis}

As the variability was high between farms, sites, and years, data from each site in each year were analyzed as a randomized complete block design using analysis of variance (ANOVA) set at $p<0.05$. The effect of different rhizobium/micronutrient treatments at each location in each year was compared with the Fisher least significant difference (lsd) method. All statistical analyses were performed using GraphPad Prism Software (v7, GraphPad Software, San Diego, CA, USA).

\section{Results}

\subsection{Nodulation Data}

At the Kaski site, which had good rainfall during the bean season in both years ( 1500-1600 mm), the average nodule number was low in 2015 (Figure 2e; note the variable y-axis scales) and increased dramatically in 2016 (Figure 2f). The Dhading site had a drought in 2015, especially just after seeding, and only moderate rainfall in 2016; perhaps as a result, the nodule number was extremely low in the former (Figure 2g), increasing only to a moderate level in 2016 (Figure 2h). There was tremendous farm-to-farm variation for nodule number (Figure 2e-h) and nodule dry weight (Figure 2i-l) within a site. In terms of general trends, the rhizobium inoculants (with or without micronutrients) had positive effects on nodulation in the wetter Kaski (Figure 2f,j) and drier Dhading (Figure 2g,k) sites compared to the untreated control plots, though not always statistically significant compared to the control plots. The micronutrient only treatment $(\mathrm{B}+\mathrm{Mo})$ did not have any significant positive effect for nodule number (Figure 2e-h) or nodule dry weight (Figure 2i-l) compared to the control. Furthermore, additive/synergistic effects were not found with the micronutrients + rhizobium treatments for nodulation in comparison to the rhizobium-only treatments (Figure 2e-1). In comparison to the respective control plots, rhizobium inoculants increased the nodulation on farms located in the wetter Kaski, whereas farms in the drier Dhading site were less benefitted in terms of absolute numbers (Table 1).

\subsection{General Effects of the Treatments on Agronomic Traits}

We expected farm-to-farm variability in the agronomic data, including yield, given the heterogeneity of the farm sites and individual practices of each household, which were unaltered. As expected, tremendous farm-to-farm variability was found within a treatment compared to across treatments for all the agronomic traits tested (Figures 2 and 3). Only a few treatment means were significantly different from the control, but were not necessarily consistent across sites and years. The greatest effect was seen in the highest rainfall site/year after rhizobium inoculation was optimized (Kaski, 2016) where the local rhizobia and/or exotic rhizobia (with or without micronutrients) increased nodulation (Figure 2f,j), plant biomass (root and shoot dry weight) (Figure 2n,r), shoot $N$ content (Figure 2v), grain yield (Figure 2z), and/or grain N content (Figure 3c). During the driest season under suboptimal rhizobium inoculation (Dhading, 2015), the local rhizobia and/or exotic rhizobia increased the nodule dry weight (Figure 2k), shoot dry weight (Figure 2s), and shoot total N content (Figure 2w) compared to the control. Similar to the nodulation trends, the micronutrient-only treatment (T2) did not significantly improve the plant biomass (Figure $2 \mathrm{~m}-\mathrm{t}$, except for Figure $2 \mathrm{n}$ ), shoot $\mathrm{N}$ content (Figure $2 \mathrm{u}-\mathrm{x}$, except for Figure $2 \mathrm{v}$ ), grain yield (Figure $2 \mathrm{y}-\mathrm{ab}$ ), and grain $\mathrm{N}$ content (Figure $3 \mathrm{c}, \mathrm{d}$ ) compared to the control. 
Table 1. The number of farms that benefitted $(+,>5 \%)$, were negatively affected $(-,<-5 \%)$, or experienced no effect $(-5 \% \leq 5 \%)$, from the rhizobium/micronutrient treatments compared to internal control plots (T1, uninoculated and without micronutrients) for the agronomic parameters tested at the Dhading and Kaski sites in 2015 and 2016

\begin{tabular}{|c|c|c|c|c|c|c|c|c|c|c|c|c|c|c|c|c|}
\hline \multirow{2}{*}{ Site/Year } & \multirow{2}{*}{ Parameter } & \multicolumn{3}{|c|}{ B + Mo (T2) } & \multicolumn{3}{|c|}{9030 Rhizobia (T3) } & \multicolumn{3}{|c|}{9030 Rhizobia + B + Mo (T4) } & \multicolumn{3}{|c|}{ Local Rhizobia (T5) } & \multicolumn{3}{|c|}{ Local Rhizobia + B + Mo (T6) } \\
\hline & & + & - & No Effect & + & - & No Effect & + & - & No Effect & + & - & No Effect & + & - & No Effect \\
\hline \multirow{6}{*}{$\begin{array}{c}\text { Total } \\
N=39\end{array}$} & Nodule \# & 20 & 14 & 5 & 25 & 7 & 7 & 17 & 18 & 4 & 22 & 14 & 3 & 12 & 6 & 1 \\
\hline & Root DWT & 20 & 15 & 4 & 20 & 14 & 5 & 26 & 10 & 3 & 23 & 11 & 1 & 13 & 6 & 0 \\
\hline & Shoot DWT & 16 & 21 & 2 & 24 & 13 & 2 & 29 & 8 & 2 & 22 & 14 & 3 & 10 & 9 & 0 \\
\hline & Shoot total N & 22 & 10 & 7 & 29 & 9 & 1 & 29 & 6 & 4 & 25 & 6 & 8 & 15 & 3 & 1 \\
\hline & Grain total N & 9 & 9 & 1 & 10 & 7 & 2 & 11 & 8 & 0 & 9 & 8 & 2 & 10 & 5 & 4 \\
\hline & Grain yield & 22 & 13 & 4 & 26 & 9 & 4 & 23 & 11 & 5 & 23 & 13 & 3 & 11 & 5 & 3 \\
\hline \multirow{5}{*}{$\begin{array}{c}\text { Kaski } \\
2015 \\
N=10\end{array}$} & Nodule \# & 4 & 4 & 2 & 6 & 1 & 3 & 3 & 6 & 1 & 4 & 5 & 1 & $\mathrm{n} / \mathrm{a}$ & $\mathrm{n} / \mathrm{a}$ & $\mathrm{n} / \mathrm{a}$ \\
\hline & Root DWT & 7 & 2 & 1 & 8 & 2 & 0 & 6 & 3 & 1 & 4 & 4 & 2 & $\mathrm{n} / \mathrm{a}$ & $\mathrm{n} / \mathrm{a}$ & $\mathrm{n} / \mathrm{a}$ \\
\hline & Shoot DWT & 4 & 5 & 1 & 6 & 3 & 1 & 9 & 0 & 1 & 7 & 1 & 2 & $\mathrm{n} / \mathrm{a}$ & $\mathrm{n} / \mathrm{a}$ & $\mathrm{n} / \mathrm{a}$ \\
\hline & Shoot total N & 3 & 5 & 2 & 7 & 3 & 0 & 8 & 0 & 2 & 7 & 2 & 1 & $\mathrm{n} / \mathrm{a}$ & $\mathrm{n} / \mathrm{a}$ & $\mathrm{n} / \mathrm{a}$ \\
\hline & Grain yield & 6 & 4 & 0 & 7 & 1 & 2 & 6 & 1 & 3 & 8 & 1 & 1 & $\mathrm{n} / \mathrm{a}$ & $\mathrm{n} / \mathrm{a}$ & $\mathrm{n} / \mathrm{a}$ \\
\hline \multirow{6}{*}{$\begin{array}{c}\text { Kaski } \\
2016 \\
N=9\end{array}$} & Nodule \# & 7 & 2 & 0 & 6 & 2 & 1 & 6 & 3 & 0 & 7 & 2 & 0 & 6 & 3 & 0 \\
\hline & Root DWT & 6 & 1 & 2 & 3 & 6 & 0 & 9 & 0 & 0 & 7 & 2 & 0 & 6 & 3 & 0 \\
\hline & Shoot DWT & 6 & 2 & 1 & 7 & 2 & 0 & 9 & 0 & 0 & 6 & 2 & 1 & 6 & 3 & 0 \\
\hline & Shoot total N & 9 & 0 & 0 & 6 & 2 & 1 & 9 & 0 & 0 & 7 & 1 & 1 & 8 & 1 & 0 \\
\hline & Grain total N & 3 & 6 & 0 & 4 & 5 & 0 & 8 & 1 & 0 & 4 & 4 & 1 & 5 & 1 & 3 \\
\hline & Grain yield & 5 & 3 & 1 & 5 & 3 & 1 & 8 & 0 & 1 & 4 & 4 & 1 & 6 & 1 & 2 \\
\hline \multirow{5}{*}{$\begin{array}{c}\text { Dhading } \\
2015 \\
N=10\end{array}$} & Nodule \# & 3 & 4 & 3 & 6 & 1 & 3 & 4 & 4 & 2 & 5 & 3 & 2 & $\mathrm{n} / \mathrm{a}$ & $\mathrm{n} / \mathrm{a}$ & $\mathrm{n} / \mathrm{a}$ \\
\hline & Root DWT & 3 & 6 & 1 & 3 & 4 & 3 & 4 & 4 & 2 & 7 & 2 & 1 & $\mathrm{n} / \mathrm{a}$ & $\mathrm{n} / \mathrm{a}$ & $\mathrm{n} / \mathrm{a}$ \\
\hline & Shoot DWT & 4 & 6 & 0 & 8 & 2 & 0 & 6 & 3 & 1 & 8 & 2 & 0 & $\mathrm{n} / \mathrm{a}$ & $\mathrm{n} / \mathrm{a}$ & $\mathrm{n} / \mathrm{a}$ \\
\hline & Shoot total N & 5 & 4 & 1 & 8 & 2 & 0 & 7 & 3 & 0 & 6 & 3 & 1 & $\mathrm{n} / \mathrm{a}$ & $\mathrm{n} / \mathrm{a}$ & $\mathrm{n} / \mathrm{a}$ \\
\hline & Grain yield & 8 & 1 & 1 & 8 & 2 & 0 & 6 & 3 & 1 & 7 & 3 & 0 & $\mathrm{n} / \mathrm{a}$ & $\mathrm{n} / \mathrm{a}$ & $\mathrm{n} / \mathrm{a}$ \\
\hline \multirow{6}{*}{$\begin{array}{c}\text { Dhading } \\
2016 \\
N=10\end{array}$} & Nodule \# & 6 & 4 & 0 & 7 & 3 & 0 & 4 & 5 & 1 & 6 & 4 & 0 & 6 & 3 & 1 \\
\hline & Root DWT & 4 & 6 & 0 & 6 & 2 & 2 & 7 & 3 & 0 & 5 & 5 & 0 & 7 & 3 & 0 \\
\hline & Shoot DWT & 2 & 8 & 0 & 3 & 6 & 1 & 5 & 5 & 0 & 1 & 9 & 0 & 4 & 6 & 0 \\
\hline & Shoot total N & 5 & 1 & 4 & 8 & 2 & 0 & 5 & 3 & 2 & 5 & 0 & 5 & 7 & 2 & 1 \\
\hline & Grain total N & 6 & 3 & 1 & 6 & 2 & 2 & 3 & 7 & 0 & 5 & 4 & 1 & 5 & 4 & 1 \\
\hline & Grain yield & 3 & 5 & 2 & 6 & 3 & 1 & 3 & 7 & 0 & 4 & 5 & 1 & 5 & 4 & 1 \\
\hline
\end{tabular}

$N=$ number of farms tested, DWT; dry weight, $\mathrm{n} / \mathrm{a}$; not applicable. $\%$ change $=[($ Treatment mean - control mean $) /$ control mean $] \times 100 \%$. 




Figure 2. Meteorological and agronomic data collected at the Dhading and Kaski sites in 2015 and 2016. (a-d) Average monthly temperature and total monthly precipitation at (a) Kaski-2015, (b) Kaski-2016, (c) Dhading-2015, and (d) Dhading-2016. For (a-d), the dotted box represents the common bean growing season; the rainfall amount noted is the accumulated rainfall during the growing season. (e-h) Number of nodules at (e) Kaski-2015, (f) Kaski-2016, (g) Dhading-2015, and (h) Dhading-2016. (i-1) Nodule dry weight at (i) Kaski-2015, (j) Kaski-2016, (k) Dhading-2015, and (1) Dhading-2016. (m-p) Root dry weight at (m) Kaski-2015, (n) Kaski-2016, (o) Dhading-2015, and (p) Dhading-2016. (q-t) Shoot dry weight at (q) Kaski-2015, (r) Kaski-2016, (s) Dhading-2015, and (t) Dhading-2016. (u-x) Shoot total nitrogen content at (u) Kaski-2015, (v) Kaski-2016, (w) Dhading-2015, and (x) Dhading-2016. (y-ab) Grain yield at (y) Kaski-2015, (z) Kaski-2016, (aa) Dhading-2015, and (ab) Dhading-2016. Each dot represents an individual farm, while horizontal solid lines represent the mean value of each treatment. Dots followed by the same letter grouping are not significantly different at $p<0.05$. $n=10$ (except $n=9$ at Kaski-2016).

Please note that the $y$-axis scales vary, as indicated by the red boxes. 
2016 - Kaski

a



2016 - Dhading

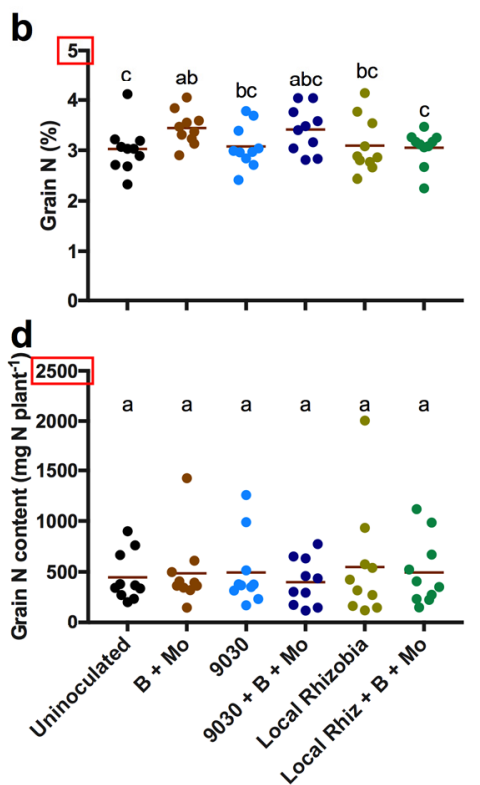

Figure 3. Grain N data collected at the Dhading and Kaski sites in 2016. (a,b) Grain N\% at (a) Kaski-2016 and (b) Dhading-2016. (c,d) Grain total N content at (c) Kaski-2016, and (d) Dhading-2016. Each dot represents an individual farm, while horizontal solid lines represent the mean value of each treatment. Dots followed by the same letter grouping are not significantly different at $p<0.05$. $n=10$ (except $n=9$ at Kaski-2016). Please note that the y-axis scales vary, as indicated by the red boxes.

\subsection{Effects of the Treatments on Agronomic Traits at an Individual Farm Level}

As a real-world development project, since smallholder farmers are risk averse, it was more informative to analyze the traits based on the number/percentage of the 39 smallholder households who benefited from, were hurt by, or unaffected (defined here as $<5 \%(+/-)$ changed compared to the respective control plots) by each treatment. In general, the majority of the smallholder farmers benefitted from the rhizobium treatments (with or without micronutrients) for the critical agronomic traits evaluated (nodule number/dry weight, vegetative dry weights, grain yield, Table 1). Out of the 39 test farms across the four trials, each rhizobium-only treatment (T3, local or T5, exotic rhizobia) benefitted up to: 25 farmers (64\%) with respect to nodule number compared to their control plots, 23 farmers (59\%) for root dry weight, 24 farmers (62\%) for shoot dry weight, 29 farmers $(74 \%)$ for shoot N, 26 farmers (67\%) for grain yield, and 10 out of 19 farmers (53\%) for grain $\mathrm{N}$ content (Table 1 ; Figure 4). A similar trend was found with each rhizobium + micronutrient treatment (out of 39 farmers for T4, or 19 farmers for T6), which benefitted up to: 63\% of farmers with respect to nodule number, $68 \%$ of farmers for root dry weight, $74 \%$ of farmers for shoot dry weight, $79 \%$ of farmers for shoot $\mathrm{N}$, $59 \%$ of farmers for grain yield, and 58\% of farmers (2016 only) for grain N content (Table 1; Figure 4). The micronutrient-only treatment (T2) had, at best, only a modest positive effect on farmers for the critical agronomic traits evaluated (see Total in Table 1). Comparing all of the treatments across the 4 trials, the exotic rhizobium-only treatment (T3) had the best impact on farmers in terms of grain yield (26 farms or $67 \%$ benefited) (Table 1; Figure 4). On the other hand, in a considerable number of farms, the rhizobium and micronutrient treatments had negative effects for the critical agronomic traits evaluated (nodule number/dry weight, vegetative dry weights, grain yield, Table 1). In general, the ratio of positively affected to negatively affected farms was 2:1 for the various traits examined (Table 1; Figure 4). 
a Kaski 2015
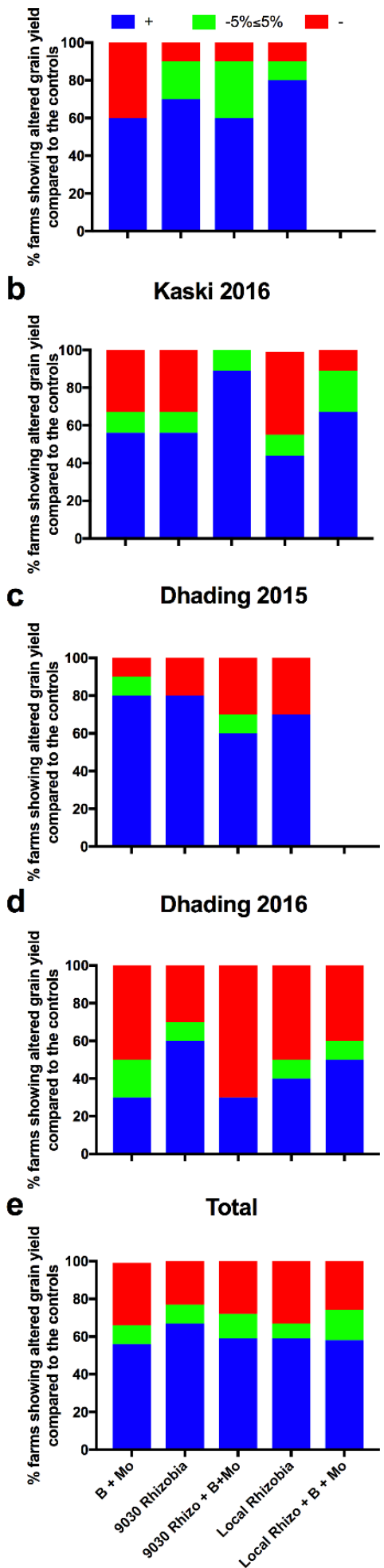

Figure 4. Summary of the percentage of farms that benefitted (+), were negatively affected $(-)$, or experienced no effect $(-5 \% \leq 5 \%)$ for grain yield, from the rhizobium/micronutrient treatments compared to the respective internal control plots (uninoculated and without micronutrients) at (a) Kaski-2015, (b) Kaski-2016, (c) Dhading-2015, (d) Dhading-2016, and (e) the total across all 4 trials. The percentage of farms showing altered grain yield $=$ (\# of farms that had positive, negative, or neutral effects/total \# of farms) $\times 100 \%$. 
The percentage increase or decrease in shoot dry weight (Supplementary Table S2), grain yield (Supplementary Table S3), and grain N content (Supplementary Table S4) of each treatment, compared to the respective control plots, was calculated. In terms of the absolute range across the 4 trials, the results show that the effects of the rhizobium and micronutrient applications were highly variable for the most critical agronomic traits: shoot biomass $(-70 \%$ to $+350 \%$, Supplementary Table S2), grain yield ( $-60 \%$ to $+900 \%$, Supplementary Table S3), and grain N content $(-60 \%$ to $+360 \%$, Supplementary Table S4). In terms of maximum yield potential, the rhizobium-only treatments (local or exotic strains) had the potential to dramatically improve the yield traits in all of the trials, despite site and climate differences (Supplementary Tables S2-S4). In terms of averages, the rhizobium-only treatments improved the average grain yield up to $140 \%$ (2015) and $43 \%$ (2016) in the wetter Kaski site, and 93\% (2015) and 8\% (2016) in the drier Dhading site, compared to the untreated control plots (Supplementary Table S3).

\section{Discussion}

Hundreds of millions of rural people globally belong to families that practice hillside farming, which is characterized by nutrient runoff, exacerbated in the subtropics by the onset of heavy rains after an extended dry season, leading to insufficient access to inorganic $N$ fertilizer $[36,37,44]$. Rhizobium inoculants are inexpensive compared to inorganic $\mathrm{N}$ fertilizers, especially critical for subsistence farmers in Asia and Sub-Saharan Africa, where poverty and access restrict synthetic fertilizer application [37,44]. When there is inadequate mineral $\mathrm{N}$ in the soil, legume crops need rhizobium inoculation under suboptimal conditions, specifically when compatible rhizobia in the soil are low/absent or ineffective for a particular legume host variety [13,15]. Furthermore, the micronutrients B and Mo are often deficient in South Asia, but are essential for optimal SNF [40,45]. This study attempted to measure the impact of rhizobia and associated micronutrients on Nepalese hillside smallholder farms in a real-world context, specifically across farm sites that were highly variable (e.g., variable soil physical and chemical properties, waterlogging, shading, Supplementary Table S1), and without disturbing variable household-specific cultivation practices (e.g., weeding, manure application, Supplementary Table S1), including diverse crop rotation histories. It is important to know whether such simple interventions can be effective without other co-inventions, in order to inform scaling up strategies.

As expected in this context, we observed tremendous farm-to-farm variation for all the agronomic parameters measured. Testing for correlations between these contextual parameters and yield components did not reveal any one strong environmental/cultural parameter underlying the variation observed (data not shown), and hence it may be that the entire system is critical. In this indigenous context, and despite the variation observed, the data showed that the number of farms that showed yield increases from rhizobium $+/-$ micronutrient interventions, compared to those that suffered yield losses, was typically in a 2:1 ratio, demonstrating the promise of these approaches for hillside smallholder farmers, even in the absence of other interventions.

\subsection{Understanding Neutral or Negative Effects of Treatments}

On some farms that we studied, rhizobium inoculation did not show any positive effects for nodulation, growth, and yield, possibly due to competition by indigenous rhizobia present in the soil [13]. The presence of local rhizobia in soil can mask the effect of rhizobium inoculants [46], as local rhizobia can compete with the introduced rhizobia, resulting in lower nodule occupancy by the latter [47] and poor survival of the introduced rhizobia in the soil [48,49]. Independent of indigenous soil rhizobia, rhizobium inoculants can have poor soil survival due to adverse environmental conditions (e.g., drought, salinity / alkalinity, extreme soil $\mathrm{pH}$, high temperatures) $[14,15,48]$. Furthermore, the lack of response to rhizobium inoculation at some farms could have been associated with adequate $\mathrm{N}$ availability in the soil, which reduces nodulation and SNF [13,50]. 
Increases in nodule number, nodule dry weight, and SNF in common bean have been observed with the application of Mo [30-33] and B [34,35]. However, in our study, application of B and Mo alone did not significantly increase nodulation in common bean, although it had a slight positive impact on root and shoot dry weight at the flowering stage. Furthermore, $50 \%$ of the farms tested showed neutral or negative impacts associated with the micronutrient-alone treatment for the agronomic traits evaluated (nodule number/dry weight, vegetative dry weights, grain yield, Table 1). One important constraint in this study is that baseline B and Mo levels could not be measured; to the best of our knowledge, there is no Mo testing lab in Nepal. It may be that the farms that did not benefit from $\mathrm{Mo} / \mathrm{B}$ had adequate soil concentrations of these micronutrients.

With regards to yield loss, in the context of the literature [24,51,52], it is difficult to understand how yield on some farms could have been apparently reduced by the treatments. However, it is important to note that some negative effects of rhizobium inoculants on climbing legume yields have been reported under real-world farmer trials in the N2Africa project as well [29]. It is known that excess soil B can cause toxicity in legumes, resulting in reduced plant growth and yield [53,54]. In our study, B (in the form of borax) was incorporated into the soil as a side-dress after one week of germination, and hence may have caused seedling toxicity from which some plants never recovered. In support of this argument, the micronutrient-only treatment had more negative effects on shoot biomass on 21 farms (Table 1). Alternatively, perhaps on some farms, the indigenous soil rhizobia may have been more optimal for the crop variety used than the introduced rhizobia; please note that the 'local rhizobia' in our experiment originated from a different region of Nepal than the trial sites. The yield declines may have been due to the allocation of more energy to maintain ineffective nodules (associated with the rhizobium interventions) since nodule development, maintenance, and SNF are energy intensive processes $[55,56]$. Unfortunately, nodule occupancy by the inoculated strains was not tested, given local infrastructure limitations.

In addition to the above biological effects, we also strongly suspect that random effects may have influenced the general results of this study, including the apparent negative impacts of the treatments, perhaps driven by the above environmental variables but at the intra-farm level (e.g., a control plot being shaded, but not an adjacent treatment plot). Independent evidence for this variability within a farm was confirmed by the high plot-to-plot variability in the number of surviving plants at harvest (up to 5-fold within an individual farm, Supplementary Table S5), despite the same number of seeds sown at the same density at all plots. Such non-uniform plant populations between adjacent plots may have added to random effects on the different agronomic traits measured (e.g., due to variation in resource availability), masking the treatment effects. Some of the extremely negative or positive yield results (e.g., K-2015-3 and K-2015-8 in Supplementary Table S3) could potentially be included in this category, since we observed that the corresponding control plots sometimes had yield values far greater or lower than the mean across farms (i.e., if a control plot had a very high yield value compared to other farms, it appeared that the treatments were detrimental, or vice versa-likely an artefact). We chose not to remove suspected outliers, in order to remain authentic to the raw data. Another factor is that cross contamination of rhizobia may have occurred among different treatment plots due to farmer management practices (e.g., through the farm tools used for earthing-up soil or weeding) or runoff between plots (since some sites were hilly), again contributing to random effects. Finally, due to field-level constraints in remote mountainous regions, low plant sampling at the flowering stage may also have caused high variability for the agronomic parameters measured. Some farms had low numbers of plants in the sub-plots due to drought and waterlogging, thus we did not want to sample many plants at the flowering stage as it could have impacted final grain yield. The later yield data is more robust, since it was collected from $9 \mathrm{~m}^{2}$ per plot.

\subsection{Understanding Variability between Trials: the Importance of Soil Moisture}

One general observable trend was that nodulation was highly influenced by the rainfall received at each site during each growing season. In 2015, Kaski received a total rainfall amount of $1525 \mathrm{~mm}$ during 
the growing season (August-December), whereas it was only $328 \mathrm{~mm}$ in Dhading. A similar trend was found in 2016 from August-December, where 1610 mm of rainfall was received in Kaski, compared to $1107 \mathrm{~mm}$ in Dhading. The 2015 drought in Dhading occurred just after sowing, and severely affected the nodule number and nodule dry weight across all the treatments, and thus, not surprisingly, there were negative effects on grain yield and grain $\mathrm{N}$ content. Furthermore, nodulation was greater on farms located at Kaski compared to Dhading, perhaps due to the higher rainfall received at the former during the growing season in both production years (Figure 2). Soil moisture availability might have been a critical factor for rhizobium survival in the soil and subsequent nodulation in our trials, as has been extensively reported [13].

In Kaski, farms that were evaluated in 2015 were located in both upland (less moist Bari land) and lowland (more moist Khet land) environments, whereas the test farms in 2016 were located only in the lowlands. However, in Dhading, all the test farms were located in the drier Bari lands in both production years. Wetter Khet lands are annually used for lowland rice production by farmers, where they apply significant amounts of farm yard manure and inorganic $\mathrm{N}$ fertilizer (rice is the main staple crop in Nepal) [57]. Furthermore, the wetter Khet lands retain more moisture in the soil, whereas the drier Bari lands retain less (due to the increased sloping of the terraces). Soil fertility in the drier Bari lands can be depleted over time, as farmers plant high $\mathrm{N}$ demanding crops (e.g., corn) with extensive root systems before the legume rotation crops. Therefore, the greater nodulation in Kaski compared to Dhading could also have been influenced by soil traits (e.g., soil moisture and fertility), in addition to the differences in rainfall received.

In the test farms located at both sites, soil should have contained native rhizobia, as nodules were observed under the uninoculated control treatment plots (Figure 2e-h). A large pool of local rhizobia has been isolated from different areas of Nepal representing different legume crops [58-62], confirming the availability of indigenous rhizobia in the Nepalese soil. Interestingly, nodulation by native soil rhizobia (control treatment-T1) was greater in farms located at Kaski compared to Dhading, which may be associated with the soil moisture conditions, which are important for rhizobia survival in the soil $[13,14,50]$. For subsistence farmers, adequate application of organic manure would be a better solution to overcome this challenge, as soil organic matter helps to hold soil moisture and build up the soil carbon pool [63] to support soil microbes.

\section{Conclusions}

In summary, the results demonstrate that even in a highly heterogenous hillside environment, and under a variety of traditional practices and cropping histories, rhizobium inoculants can benefit farmers (improving nodulation, plant growth, and grain yield) in a 2:1 ratio, even in the absence of co-interventions. Some farmers showed apparently remarkable benefits from rhizobium inoculation, while others did not. In this real-world context, the treatments were associated with an apparent tremendous farm-to-farm variability for nodulation, vegetative biomass, shoot $\mathrm{N}$ content, grain yield, and grain $\mathrm{N}$ content. Plot-to-plot variation within each farm and limited sampling (at the flowering stage) may have created experimental artefacts, including some of the extreme positive and negative results. It was clear that the success of the rhizobium inoculants was highly influenced by the rainfall received during the growing season. For these technologies to be effective across a highly variable hillside context, supporting interventions may be needed.

Supplementary Materials: The following are available online at http:/ / www.mdpi.com/2077-0472/9/1/20/s1, Table S1: Farm specific details, Table S2: Percentage (\%) change in shoot dry weight at the flowering stage associated with rhizobia-micronutrient treatments compared to internal control plots at individual farms at the Kaski and Dhading sites in 2015 and 2016, Table S3: Percentage (\%) change in grain yield associated with rhizobia-micronutrient treatments compared to internal control plots at individual farms at the Kaski and Dhading sites in 2015 and 2016, Table S4: Percentage (\%) change in grain total nitrogen content associated with rhizobia-micronutrient treatments compared to internal control plots at individual farms at the Kaski and Dhading sites in 2015 and 2016, Table S5: Number of plants per $9 \mathrm{~m}^{2}$ at harvest in each treatment plot in farms located at individual farms at the Kaski and Dhading sites in 2015 and 2016. 
Author Contributions: Conceptualization, M.S.T., M.N.R. and T.C.; Methodology, M.S.T., T.C. and R.P.; Investigation, M.S.T.; Resources, M.S.T., M.N.R., R.P., S.G. and K.C.; Data Curation, M.S.T., B.G., B.B.T., K.G., L.R., S.M. and B.B.; Formal Analysis, M.S.T.; Writing-Original Draft Preparation, M.S.T.; Writing-Review and Editing, M.S.T., T.C. and M.N.R.; Supervision, M.N.R.

Funding: This research was supported by CIFSRF grant 107791 from the International Development Research Centre (IDRC, Ottawa) and Global Affairs Canada.

Acknowledgments: We acknowledge our generous Nepalese farmer partners in the Kaski and Dhading districts who participated in the on-farm trials. The authors are grateful to additional staff at LIBIRD (a Nepalese NGO) especially field staff who helped in numerous ways including trial establishment and sample collection. We acknowledge Timothy Porch (USDA) for providing the exotic rhizobia strain. We thank Kamal Khadka (LI-BIRD, Nepal and University of Guelph) for initiating the SAK-Nepal project. Special thanks to Sanda Jovasevic (Plant-Prod ON, Canada) for providing micronutrients for the trials. We also acknowledge Bishnu Hari Adhikary and Sanu Keshari Bajracharya (NARC, Nepal).

Conflicts of Interest: The authors declare that the research was conducted in the absence of any commercial or financial relationships that could be construed as a potential conflict of interest.

\section{References}

1. Leigh, G.J. The Worlds Greatest Fix: A History of Nitrogen and Agriculture; Oxford University Press: Oxford, UK, 2004.

2. Foyer, C.H.; Lam, H.; Nguyen, H.T.; Siddique, K.H.M.; Varshney, R.K.; Colmer, T.D.; Cowling, W.; Bramley, H.; Mori, T.A.; Hodgson, J.M.; et al. Neglecting legumes has compromised human health and sustainable food production. Nat. Plants 2016, 2, 1-10. [CrossRef] [PubMed]

3. Mpepereki, S.; Javaheri, F.; Davis, P.; Giller, K.E. Soyabeans and sustainable agriculture Promiscuous soyabeans in southern Africa. Field Crops Res. 2000, 65, 137-149. [CrossRef]

4. Graham, P.H.; Vance, C.P. Legumes: Importance and constraints to greater use. Plant Physiol. 2003, 131, 872-877. [CrossRef] [PubMed]

5. Herridge, D.F.; Peoples, M.B.; Boddey, R.M. Global inputs of biological nitrogen fixation in agricultural systems. Plant Soil 2008, 311, 1-18. [CrossRef]

6. Hauggaard-Nielsen, H.; Jørnsgaard, B.; Kinane, J.; Jensen, E.S. Grain legume-cereal intercropping: The practical application of diversity, competition and facilitation in arable and organic cropping systems. Renew. Agric. Food Syst. 2008, 23, 3-12. [CrossRef]

7. Fustec, J.; Lesuffleur, F.; Mahieu, S.; Cliquet, J.B. Nitrogen rhizodeposition of legumes. A review. Agron. Sustain. Dev. 2010, 30, 57-66. [CrossRef]

8. Thilakarathna, M.S.; Papadopoulos, Y.A.; Grimmett, M.; Fillmore, S.A.E.; Crouse, M.; Prithiviraj, B. Red clover varieties show nitrogen fixing advantage during the early stages of seedling development. Can. J. Plant Sci. 2018, 98, 1-10. [CrossRef]

9. Thilakarathna, M.S.; Mcelroy, M.S.; Chapagain, T.; Papadopoulos, Y.A.; Raizada, M.N. Belowground nitrogen transfer from legumes to non-legumes under managed herbaceous cropping systems. A review. Agron. Sustain. Dev. 2016, 36, 58. [CrossRef]

10. Chapagain, T.; Riseman, A. Barley-Pea intercropping: Effects on land productivity, carbon and nitrogen transformations. Field Crops Res. 2014, 166, 18-25. [CrossRef]

11. Thilakarathna, M.S.; Papadopoulos, Y.A.; Rodd, A.V.; Grimmett, M.; Fillmore, S.A.E.; Crouse, M.; Prithiviraj, B. Nitrogen fixation and transfer of red clover genotypes under legume-grass forage based production systems. Nutr. Cycl. Agroecosyst. 2016, 106, 233-247. [CrossRef]

12. Gan, Y.; Hamel, C.; O’Donovan, J.T.; Cutforth, H.; Zentner, R.P.; Campbell, C.A.; Niu, Y.; Poppy, L. Diversifying crop rotations with pulses enhances system productivity. Sci. Rep. 2015, 5, 14625. [CrossRef]

13. Thilakarathna, M.S.; Raizada, M.N. A meta-analysis of the effectiveness of diverse rhizobia inoculants on soybean traits under field conditions. Soil Biol. Biochem. 2017, 105, 177-196. [CrossRef]

14. Zahran, H.H. Rhizobium-legume symbiosis and nitrogen fixation under severe conditions and in an arid climate. Microbiol. Mol. Biol. Rev. 1999, 63, 968-989. [PubMed]

15. Giller, K.E. Nitrogen Fixation in Tropical Cropping Systems; CABI: Wallingford, UK, 2001.

16. Bolaños, L.; Esteban, E.; De Lorenzo, C.; Fernandez-Pascual, M.; De Felipe, M.R.; Garate, A.; Bonilla, I. Essentiality of boron for symbiotic dinitrogen fixation in pea (Pisum sativum) Rhizobium nodules. Plant Physiol. 1994, 104, 85-90. [CrossRef] 
17. Gepts, P.; Debouck, D. Origin, domestication, and evolution of the common bean (Phaseolus vulgaris L.). In Common Bean: Research for Crop Improvement; Schoonhoven, A., van Voysest, O., Eds.; CIAT: Cali, Colombia, 1991; pp. 7-53.

18. Broughton, W.J.; Herna'ndez, G.; Blair, M.; Beebe, S.; Gepts, P.; Vanderleyden, J. Beans (Phaseolus spp.)-Model food legumes. Plant Soil 2003, 252, 55-128. [CrossRef]

19. Graham, P.H.; Ranalli, P. Common bean (Phaseolus vulgaris L.). Field Crops Res. 1997, 53, 131-146. [CrossRef]

20. Beebe, S.; Ramirez, J.; Jarvis, A.; Rao, I.M.; Mosquera, G.; Bueno, J.M.; Blair, M.W. Genetic improvement of common beans and the challenges of climate change. In Crop Adaptation to Climate Change; Yadav, S.S., Redden, R.J., Hatfield, J.L., Lotze-Campen, H., Hall, A.E., Eds.; John Wiley \& Sons, Ltd.: Richmond, Australia, 2011; pp. 356-369.

21. Bliss, F.A. Breeding common bean for improved biological nitrogen fixation. Plant Soil 1993, 152, 71-79. [CrossRef]

22. Hardarson, G.; Atkins, C. Optimising biological $\mathrm{N}_{2}$ fixation by legumes in farming systems. Plant Soil 2003, 252, 41-54. [CrossRef]

23. Rurangwa, E.; Vanlauwe, B.; Giller, K.E. Benefits of inoculation, P fertilizer and manure on yields of common bean and soybean also increase yield of subsequent maize. Agric. Ecosyst. Environ. 2018, 261, 219-229. [CrossRef] [PubMed]

24. Chekanai, V.; Chikowo, R.; Vanlauwe, B. Response of common bean (Phaseolus vulgaris L.) to nitrogen, phosphorus and rhizobia inoculation across variable soils in Zimbabwe. Agric. Ecosyst. Environ. 2018, 266, 167-173. [CrossRef] [PubMed]

25. Ndakidemi, P.A.; Dakora, F.D.; Nkonya, E.M.; Ringo, D.; Mansoor, H. Yield and economic benefits of common bean (Phaseolus vulgaris) and soybean (Glycine max) inoculation in northern Tanzania. Aust. J. Exp. Agric. 2006, 46, 571-577. [CrossRef]

26. Da Silva, P.M.; Tsai, S.M.; Bonetti, R. Response to inoculation and N-fertilization for increased yield and biological nitrogen-fixation of common bean (Phaseolus vulgaris L.). Plant Soil 1993, 152, 123-130. [CrossRef]

27. Chianu, J.; Nkonya, E.; Mairura, F.; Chianu, J.; Akinnifesi, F. Biological nitrogen fixation and socioeconomic factors for legume production in sub-Saharan Africa: Review. Agron. Sustain. Dev. 2011, 31, 139-154. [CrossRef]

28. Musandu, A.A.O.; Joshua, O.O. Response of common beans to Rhizobium innoculation and fertilizers. J. Food Technol. Afr. 2001, 6, 121-125. [CrossRef]

29. Giller, K.E. N2Africa Putting Nitrogen Fixation to Work for Smallholder Farmers in Africa, Podcaster No. 28, October, November, December 2014 (No. 28). N2Africa Project. 2014. Available online: https: / / n2africa.org/sites/default/files/N2Africa-Podcaster-28.pdf (accessed on 10 January 2019).

30. Bambara, S.; Ndakidemi, P.A. Effects of Rhizobium inoculation, lime and molybdenum on photosynthesis and chlorophyll content of Phaseolus vulgaris L. Afr. J. Microbiol. Res. 2009, 3, 791-798.

31. Silva, A.; Franzini, V.I.; Piccolla, C.D.; Muraoka, T. Molybdenum supply and biological fixation of nitrogen by two Brazilian common bean cultivars. Rev. Bras. Eng. Agrícola e Ambient. 2017, 21, 100-105. [CrossRef]

32. Vieira, R.F.; Cardoso, E.J.B.N.; Vieira, C.; Cassini, S.T.A. Foliar application of molybdenum in common beans. I. Nitrogenase and reductase activities in a soil of high fertility. J. Plant Nutr. 1998, 21, 169-180. [CrossRef]

33. Vieira, R.F.; Vieira, C.; Cardoso, E.J.B.N.; Mosquim, P.R. Foliar application of molybdenum in common bean. II. Nitrogenase and nitrate reductase activities in a soil of low fertility. J. Plant Nutr. 1998, 21, 2141-2151. [CrossRef]

34. Ganie, M.A.; Akhter, F.; Bhat, M.A.; Najar, G.R. Growth, yield and quality of french bean (Phaseolus vulgaris L.) as influenced by sulphur and boron application on inceptisols of Kashmir. Bioscan 2014, 9, 513-518.

35. Redondo-Nieto, M.; Wilmot, A.R.; El-Hamdaoui, A.; Bonilla, I.; Bolaños, L. Relationship between boron and calcium in the $\mathrm{N}_{2}$-fixing legume-rhizobia symbiosis. Plant Cell Environ. 2003, 26, 1905-1915. [CrossRef]

36. Chapagain, T.; Raizada, M.N. Agronomic challenges and opportunities for smallholder terrace agriculture in developing countries. Front. Plant Sci. 2017, 8, 1-15. [CrossRef] [PubMed]

37. Small, F.A.A.; Raizada, M.N. Mitigating dry season food insecurity in the subtropics by prospecting drought-tolerant, nitrogen-fixing weeds. Agric. Food Secur. 2017, 6, 1-14. [CrossRef]

38. Franke, A.C.; Baijukya, F.; Kantengwa, S.; Reckling, M.; Vanlauwe, B.; Giller, K.E. Poor farmers-poor yields: Socio-economic, soil fertility and crop management indicators affecting climbing bean productivity in northern Rwanda. Exp. Agric. 2016, 1-21. [CrossRef] 
39. Gharti, D.B.; Darai, R.; Subedi, S.; Sarker, A.; Kumar, S. Grain legumes in Nepal: Present scenario and future prospects. World J. Agric. Res. 2014, 2, 216-222. [CrossRef]

40. Andersen, P. A review of micronutrient problems in the cultivated soil of Nepal. Mt. Res. Dev. 2007, 27, 331-335. [CrossRef]

41. Anderson, J.M.; Ingram, J.S.I. Tropical Soil Biology and Fertility: A Handbook of Methods, 2nd ed.; CAB International: Wallingford, UK, 1993.

42. Somasegaran, P.; Hoben, H.J. Handbook for Rhizobia. Methods in Legume-Rhizobium Technology; Springer: Heidelberg, Germany, 1994.

43. van Berkum, P.; Beyene, D.; Eardly, B.D. Phylogenetic relationships among Rhizobium species nodulating the common bean (Phaseolus vulgaris L.). Int. J. Syst. Bacteriol. 1996, 46, 240-244. [CrossRef] [PubMed]

44. Thilakarathna, M.S.; Raizada, M.N. A review of nutrient management studies involving finger millet in the Semi-Arid Tropics of Asia and Africa. Agronomy 2015, 5, 262-290. [CrossRef]

45. Thilakarathna, M.S.; Raizada, M.N. Challenges in using precision agriculture to optimize symbiotic nitrogen fixation in legumes: Progress, limitations, and future improvements needed in diagnostic testing. Agronomy 2018, 8, 78. [CrossRef]

46. Van Kessel, C.; Hartley, C. Agricultural management of grain legumes: Has it led to an increase in nitrogen fixation? Field Crops Res. 2000, 65, 165-181. [CrossRef]

47. Sanz-Sáez, Á.; Heath, K.D.; Burke, P.V.; Ainsworth, E.A. Inoculation with an enhanced $\mathrm{N}_{2}$-fixing Bradyrhizobium japonicum strain (USDA110) does not alter soybean (Glycine max Merr.) response to elevated [CO ${ }_{2}$ ]. Plant Cell Environ. 2015, 38, 1-14. [CrossRef] [PubMed]

48. Hungria, M.; Vargas, M.A.T. Environmental factors affecting $\mathrm{N}_{2}$ fixation in grain legumes in the tropics, with an emphasis on Brazil. Field Crops Res. 2000, 65, 151-164. [CrossRef]

49. Albareda, M.; Rodri'guez-Navarro, D.N.; Temprano, F.J. Soybean inoculation: Dose, N fertilizer supplementation and rhizobia persistence in soil. Field Crops Res. 2009, 113, 352-356. [CrossRef]

50. Liu, Y.; Wu, L.; Baddeley, J.A.; Watson, C.A. Models of biological nitrogen fixation of legumes. A review. Agron. Sustain. Dev. 2011, 31, 155-172. [CrossRef]

51. van Heerwaarden, J.; Baijukya, F.; Kyei-Boahen, S.; Adjei-Nsiah, S.; Ebanyat, P.; Kamai, N.; Wolde-meskel, E.; Kanampiu, F.; Vanlauwe, B.; Giller, K. Soyabean response to rhizobium inoculation across sub-Saharan Africa: Patterns of variation and the role of promiscuity. Agric. Ecosyst. Environ. 2018, 261, 211-218. [CrossRef] [PubMed]

52. Ronner, E.; Franke, A.C.; Vanlauwe, B.; Dianda, M.; Edeh, E.; Ukem, B.; Bala, A.; Van Heerwaarden, J.; Giller, K.E. Understanding variability in soybean yield and response to P-fertilizer and rhizobium inoculants on farmers' fields in northern Nigeria. Field Crops Res. 2016, 186, 133-145. [CrossRef]

53. Bogacki, P.; Peck, D.M.; Nair, R.M.; Howie, J.; Oldach, K.H. Genetic analysis of tolerance to Boron toxicity in the legume Medicago truncatula. BMC Plant Biol. 2013, 13, 54. [CrossRef] [PubMed]

54. Bagheri, A.; Paull, J.G.; Rathjen, A.J.; Ali, S.M.; Moody, D.B. Genetic variation in the response of pea (Pisum sativum L.) to high soil concentrations of boron. Plant Soil 1992, 146, 261-269. [CrossRef]

55. Ribet, J.; Drevon, J.J. The phosphorus requirement of $\mathrm{N}_{2}$-fixing and urea-fed Acacia mangium. New Phytol. 1996, 132, 383-390. [CrossRef]

56. Puppo, A.; Groten, K.; Bastian, F.; Carzaniga, R.; Soussi, M.; Lucas, M.M.; De Felipe, M.R.; Harrison, J.; Vanacker, H.; Foyer, C.H. Legume nodule senescence: Roles for redox and hormone signalling in the orchestration of the natural aging process. New Phytol. 2005, 165, 683-701. [CrossRef]

57. Chapagain, T.; Pudasaini, R.; Ghimire, B.; Gurung, K.; Choi, K.; Rai, L.; Magar, S.; BK, B.; Raizada, M.N. Intercropping of maize, millet, mustard, wheat and ginger increased land productivity and potential economic returns for smallholder terrace farmers in Nepal. Field Crops Res. 2018, 227, 91-101. [CrossRef]

58. Adhikari, D.; Kaneto, M.; Itoh, K.; Suyama, K.; Pokharel, B.B.; Gaihre, Y.K. Genetic diversity of soybean-nodulating rhizobia in Nepal in relation to climate and soil properties. Plant Soil 2012, 357, $131-145$. [CrossRef]

59. Adhikari, D.; Itoh, K.; Suyama, K. Genetic diversity of common bean (Phaseolus vulgaris L.) nodulating rhizobia in Nepal. Plant Soil 2013, 368, 341-353. [CrossRef]

60. Baral, B.; Gupta, V.N. Symbiotic properties of rhizobial isolates of Manang and Kathmandu districts. Nepal J. Sci. Technol. 2010, 11, 95-100. [CrossRef] 
61. Risal, C.P.; Djedidi, S.; Dhakal, D.; Ohkama-Ohtsu, N.; Sekimoto, H.; Yokoyama, T. Phylogenetic diversity and symbiotic functioning in mungbean (Vigna radiata L. Wilczek) bradyrhizobia from contrast agro-ecological regions of Nepal. Syst. Appl. Microbiol. 2012, 35, 45-53. [CrossRef] [PubMed]

62. Risal, C.P.; Yokoyama, T.; Ohkama-Ohtsu, N.; Djedidi, S.; Sekimoto, H. Genetic diversity of native soybean bradyrhizobia from different topographical regions along the southern slopes of the Himalayan Mountains in Nepal. Syst. Appl. Microbiol. 2010, 33, 416-425. [CrossRef] [PubMed]

63. Zengeni, R.; Mpepereki, S.; Giller, K.E. Manure and soil properties affect survival and persistence of soyabean nodulating rhizobia in smallholder soils of Zimbabwe. Appl. Soil Ecol. 2006, 32, 232-242. [CrossRef]

(C) 2019 by the authors. Licensee MDPI, Basel, Switzerland. This article is an open access article distributed under the terms and conditions of the Creative Commons Attribution (CC BY) license (http:/ / creativecommons.org/licenses/by/4.0/). 